\title{
Seismicity of Turkey and Real-Time Seismology Applications in Determining Earthquake Hazard
}

\author{
Dogan Kalafat $^{1}$ iD, A. Can Zulfikar²* iD, Seyhan Okuyan Akcan ${ }^{3}$ iD \\ ${ }^{1}$ Kandilli Observatory and Earthquake Research Institute, Boğaziçi University, Turkey \\ ${ }^{2}$ Department of Civil Engineering, Gebze Technical University, Turkey \\ ${ }^{3}$ Department of Civil Engineering, Boğaziçi University, Turkey
}

Received: / Accepted: 21-December-2021 / 31-December-2021

\begin{abstract}
Turkey is between three major tectonic plates, is the most active area of the Mediterranean region in terms of earthquake activity. Relative motions between the African, Arabian and Eurasian plates account for most of the tectonic activity in the region. As a result, the Anatolian plate has a high danger for seismicity. This consists of the North Anatolian Fault Zone (NAFZ), East Anatolian Fault Zone (EAFZ) and SE Anatolian Thrust Zone which form the borders of the Anatolian Plate and important active fault segments throughout Western Anatolia. All these active faults cause a short time intervals intensive damages in Turkey earthquakes. In order to investigate and to real-time monitor the seismic activity and seismotectonic of Turkey and its vicinity, The Kandilli Observatory and Earthquake Research Institute (KOERI) of Bogaziçi University and AFAD operates seismic stations countrywide. Observatory has been supplying mainly 3 kind of seismological data: phase readings, waveform and catalogue to the earth scientists in Turkey. Earth science studies have an important contribution to the emergence of earthquake hazard. The evaluation of the data receiving from the seismic stations contributes to the determination of earthquake hazard in detail, and to contribute to the minimization of the risks of the earthquake by developing earthquake catalogues. Also, all of the earthquake parameters after the earthquake, automatically distributed and mapped. After an important earthquake, KOERI and AFAD is quickly sent information from the smartphones to the society and the decision-making institutions carrying out disaster studies.
\end{abstract}

Key words: Real-Time Seismology, Earthquake Hazard, Seismicity of Turkey

\section{Introduction}

Turkey is one of the most important seismic active countries in the world. Turkey is between three major tectonic plates, and compressed towards the north by Arabian and African plates. This region is the most active area of the Mediterranean region in terms of earthquake activity. The observed earthquakes are generated as a result of the collision of the Arabian and African plates with Eurasia. Although a number of plates having different sizes on the region based on the spatial distribution of the seismicity, mainly three plate boundaries play important roles. These are the African, Arab and Eurasian plates. The Turkish/Anatolian plate is surrounded by African and Arabian plates in the south, the Eurasian plate in the north and the Aegean plate in the west. Relative motions between the African, Arabian and Eurasian plates account for most of the tectonic activity in the region. As a result, the Anatolian plate has a high danger for seismicity. This consists of the North Anatolian Fault Zone (NAFZ), East Anatolian Fault Zone

\footnotetext{
* Corresponding Author e-mail: aczulfikar@gtu.edu.tr
} 
(EAFZ) and South Eastern Anatolian Thrust Zone (SAT) which form the borders of the Anatolian Plate and important active fault segments throughout Western Anatolia. All these active faults cause a short time intervals intensive damages in Turkey earthquakes, which in turn is a significant risk of earthquake in Turkey [1].

In the last century, the destructive earthquakes have occurred along the North Anatolian Fault Zone (NAFZ). Figure 1 shows the fault zones around Turkey. The NAF, EAF and Southeast Anatolian Thrust (SAT) zone are the major structures in Turkey, whereas the Dead Sea fault zone (DSF), Aegean arc, Cyprus Arc, Pontic Escarpment, Great and Lesser Caucasus are the main megastructures responsible for the seismicity around Turkey [2].

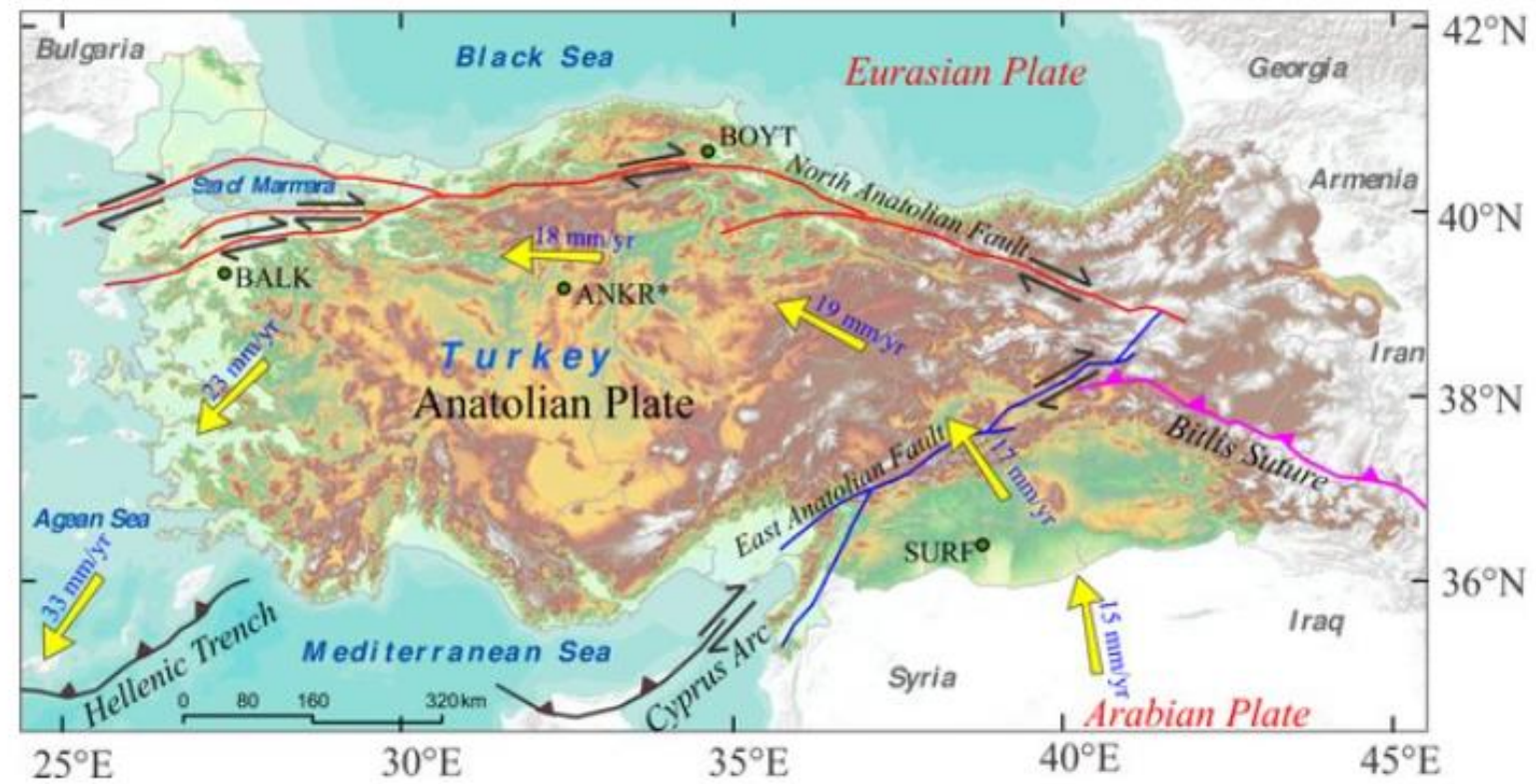

Figure 1. Map showing main tectonic structures around the Anatolian Plate [3]

Turkey have different and complex tectonic structure that shows the high risk to earthquakes in Turkey. Normal faults,reverse faults,strike slip faults and oblique fault mechanism are the seen as fault mechanism in Turkey as shown at Figure 2.

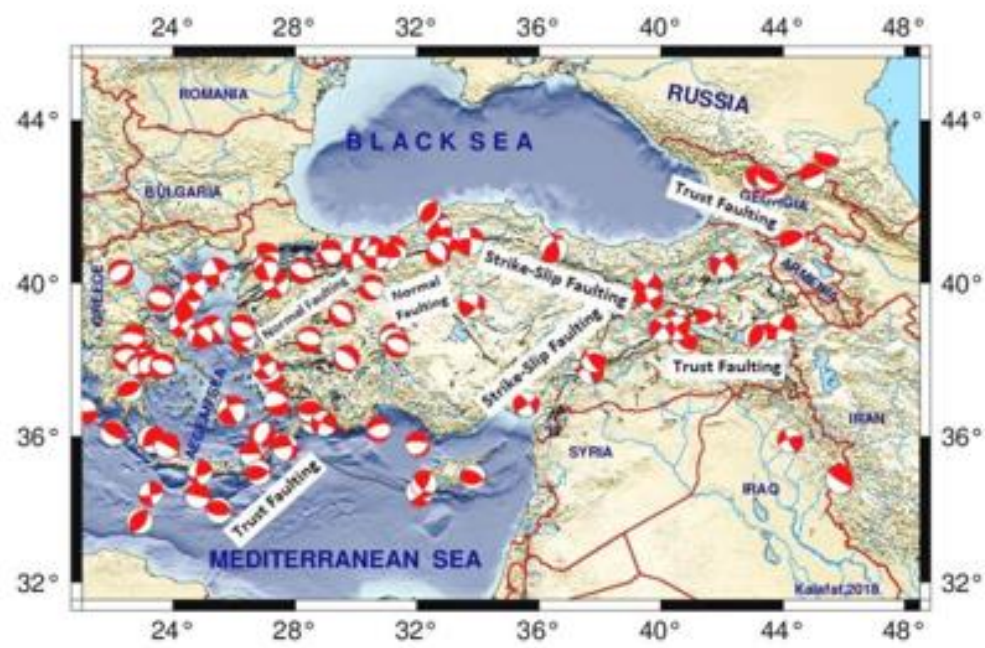

Figure 2. Fault Mechanism of the Earthquakes around Turkey [4] 
The NAFZ is one of the most important active strike slip faults. It is important for the tectonics of the Eastern Mediterranean region. The fault zone is about $1500 \mathrm{~km}$ long, extending from Karliova triple junction in eastern Turkey to mainland Greece [5]. Figure 3 shows the ocuured earthqaukes with Mw>7 between 1939-1999 along the NAFZ.

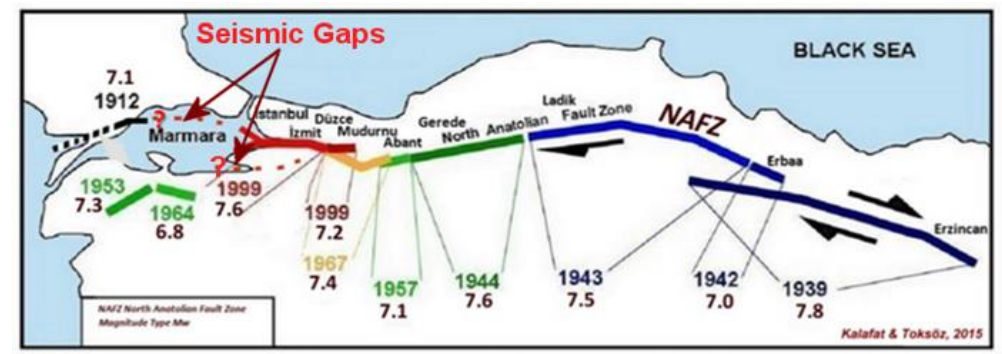

Figure 3. Major earthquakes along the North Anatolian fault (NAF) since the December 26, 1939, Erzincan earthquake [6]

Between 1939 and 1999, the NAF ruptured in a sequence of large earthquakes $(M>7)$ initiated by $1939 \mathrm{Mw} 7.9$ Erzincan earthquake and propagated westward over $1000 \mathrm{~km}$ and August 17, 1999, Mw 7.6 İzmit earthquake ruptured a 150-km-long segment of the NAF [1].Chronologically, these events are the December 27, 1939, Erzincan earthquake (Ms 7.9), the December 20, 1942, Erbaa-Niksar earthquake (Ms 7.1), the November 26, 1943, Tosya earthquake (Ms 7.4), the February 1, 1944, Bolu-Gerede earthquake (Ms 7.3), the May 26, 1957, Abant earthquake (Ms 7.1), the July 22, 1967, Mudurnu earthquake (Ms 7. 2), the March 13, 1992, Erzincan earthquake (Mw 6.3), the August 17, 1999, İzmit earthquake (Mw 7.4) and the November 12, 1999, Düzce earthquake (Mw 7.2). The 1999 İzmit and Düzce earthquakes developed as the last in the earthquake migration series on the NAF [2]. Additionally, two large events, the December 8, 1905 (Ms 7.4) and September 26, 1932 (Ms 7.1), occurred in the North Aegean Trough and appear related to the westernmost part of the NAF zone [2].The seismic source in northern Turkey was the product of a major, active, dextral strike-slip fault and after Yenice- Gönen earthquake [2].

The East Anatolian Fault Zone (EAFZ) is a band of active seismicity and tectonism that joins the eastern end of the North Anatolian Fault Zone (NAFZ) to the Mediterranean Sea in the Gulf of İskenderun. It is much less distinct, both morphologically and structurally, than the North Anatolian Fault Zone that ruptured almost along its entire length in a series of large earthquakes between 1939 and 2000 [7].

The EAF zone is $580 \mathrm{~km}$ long and forms a complex sinistral strike-slip fault zone boundary between the Anatolian and Arabian plates. The EAF is separated into northern and southern fault strands to the west and becomes a wide deformation zone. The southern strand of the EAF zone is between Karlıova and Çelikhan and is composed of seven fault segments [8]. The northern strand of the EAF zone, consists of 8 fault segments, which exhibits distinctive active left-lateral fault features [8].

Although the EAF zone produces moderate earthquakes during the instrumental period, they are not characteristic large earthquakes for the EAF [2]. The EAF experienced a sequence of large earthquakes during the last two centuries, accompanied by surface ruptures [9]. These include the 1866 earthquake (Ms 7.2), 1874 earthquake (Ms 7.1), 1893 earthquake (Ms 7.1) and 1971 earthquake (Ms 6.8) and are generated on the Karlıva, Palu, Erkenek and Ilıca segments of the EAF, respectively.Additionally, the 1905 (Ms 6.8) [6] and the 2010 (Mw 6.1 and 6.0) earthquakes [10] occurred on the Yarpuzlu and the Gökdere restraining bends, respectively. 
Southeast Anatolian fault zone includes 45 identified fault segments. However, the SAT zone characterizes and almost encompasses the domain. The majority of the fault segments are characterized as reverse and dextral strike-slip motions structures. The rest of the segments have sinistral strike-slip or normal slip motions [2]. In total, 241 earthquakes (Mw 4.0-6.5) were recorded in this domain between 1900 and 2012. The largest event was the September 6, 1975, Lice event (Ms 6.6) that occurred on the Lice segment of the SAT zone which resulted in surface rupture [2].

There are different seismic Pattern in Turkey [11]. It can be seen at Figure 4 as examples of patterns of earthquake occurrence in Turkey. 1/10/1995 Dinar earthqauke, there are fore shocks and after scock activities. 17/08/1999 Gölcük earthqauke, there are only after chock activites. 1/12/1985 Balıkesir earthqauke, there are only earthqauke swarm. Between 2005 and 2007Afşar earthquake, there are earthqauke series.

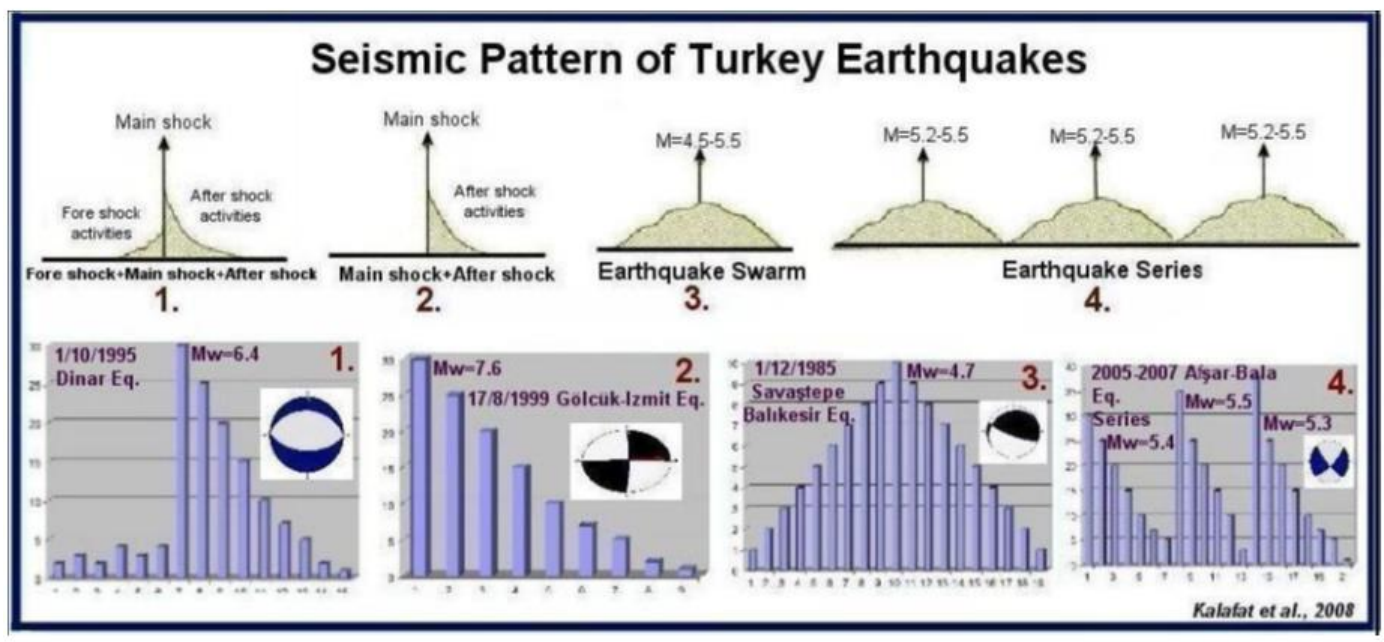

Figure 4. Different Seismic Pattern in Turkey [11]

Seismological studies are very important for the determination of seismic hazard.Today, in order to investigate and to real-time monitor the seismic activity and seismotectonic of Turkey and its vicinity, real-time seismic monitoring is carried out with Kandilli and AFAD earthquake stations spread across the country. Modern technological equipment and communication systems are used in all stations. The evaluation of the data receiving from seismic stations contributes to the determination of earthquake hazard in detail, and to contribute to the minimization of the risks of the earthquake. All of the earthquake parameters after the earthquake, are distributed automatically. Also, estimated life losses, shaking maps and damage maps are produced immediately after the earthquake.

Real-time seismology is achieved by three kind sof seismological observations which are phase readings, waveforms and catalogues [1].The earthquake catalogues are the first output of seismological observations. Several institutions around the world generate national and international catalogues for understanding the seismic activity of a region. Principally, a catalogue contains the parameters such as origin time, coordinates, and focal depth [10].

Earthquake parameters can be obtained from seismological monitoring studies. Earthquake catalogs are created by combining past earthquakes and related earthquake parameters,and they catalogs lead the way especially in earthquake risk studies. By using catalogs, information about possible earthquake recurrence periods is obtained. It is make important contributions to the engineering studies to be done.Also, information about the earthquake potentials of the settlements is obtained. 
Earthquake catalogs, which are created by seismological observations, have an important role in determining the mechanisms of occurrence of future earthquakes, their possible locations, effects and damage to structures. In other words, earthquake catalogs have important contributions in obtaining seismic hazard maps and calculating seismic risk. One of the major steps of an earthquake hazard and risk assessment study is to compile a complete earthquake catalogue for the region of interest including all seismological parameters related with these events [12].

Earthquake catalogues prepared by different institutions and researchers have provided considerable amount of data for Turkey and its surrounding areas since 1950s. The some of prominent catalogues can be listed as; Gutenberg and Richter (1954), Alsan et al. (1975), Ayhan et al. (1981), Ambraseys and Finkel (1987), Ambraseys and Jackson (1998), Kalafat et al. (2011), and Disaster and Emergency Management Presidency of Turkey (AFAD) Catalogue [12].

Kalafat [16] developed an earthquake catalog contains a data set of all earthquakes with a magnitude of $\mathrm{M} \geq 4.0$ that have occurred in Turkey and its immediate surroundings from the beginning of the instrumental period (1900) to the present (2005). Kalafat (2006) examined the 105 years of earthquake activity. The number of earthquakes in this period $(M \geq 4.0)$ is determined as 8360 in total. In the area under consideration, there are regions with high earthquake activity such as the Eastern Mediterranean, the Aegean, the Balkans, the Sea of Marmara and its east, Central and Northeastern Anatolia, Eastern and Southeastern Anatolia, Cyprus and the Iraq-Iran border, and the Caucasus.

Kadirioglu et al.(2016) has published an improved earthqauke catalog ( $\mathrm{M}>4.0)$ for Turkey and its vicinity (1900-2012). The available catalogues for Turkey have some deficiencies such as magnitude heterogeneity, some uncertainties and errors on epicentral location, date and time that may lead to unreliable results in seismic hazard and risk studies. These ambiguities reinforced the need for an improved and updated catalogue to support the earthquake hazard and risk assessments [9]. This improved earthquake catalogue contains 12,674 events spanning a period of 1900-2012. The events of $\mathrm{M}<6.0$ and 5.0 $<\mathrm{M}<6.0$ are 203 and 1468, respectively. The homogenized the catalogue is complete above $\mathrm{Mw}$ 4.3. After declustering, that is removal of fore- and aftershocks, the catalogue consist of 6573 events [12].

Seismic hazard assessment is essential for hazard management efforts such as earthquakeresistant design policies, risk analyses and land-use planning studies. Earthquake geoscience is a rapidly evolving field, and seismic hazard maps need to be revised or updated systematically with the progress in methodology and the accretion of new seismotectonic data. Earlier seismic hazard studies for Turkey include those by [20], 21] and [22]. The most recent efforts were carried out as part of the Seismic Hazard Harmonization in Europe (SHARE) [20] and Earthquake Model of the Middle East Region (EMME — http://www.emme-gem.org/) projects, where Turkey is the common country in both projects [2].

Earthquake risk depends on the geological and tectonic structure in the region. Seismology department works on the determination of geological structure and tectonic structure. With the increase in the number of seismic stations and the increase in their sensitivity, the acquisition and analysis of earthquake parameters becomes more sensitive and reliable.

Earthquake Department of Republic of Turkey Prime Ministry's Disaster and Emergency Management Presidency (AFAD), and Kandilli Observatory and Earthquake Research Institute 
(KOERI) of Bogazici University are the two main seismic network operators in Turkey. They periodically publish data in the form of catalogues and bulletins for internal and external information exchange. To mitigate the seismic risk and prevent seismic panic, the KOERI and AFAD have for improving the seismic monitoring system by establishment the broadband digital seismic network in Turkey. Such monitoring system permit rapid acquisition of seismic wave form data, automatic detection of earthquake event and hypocenter determination. The system also provides high quality data appropriate to study on seismology and tectonic as well as earthquake prediction. Today, KOERI Seismic Network has 450 stations, AFAD has 795 stations in the whole of Turkey at Figure 5.

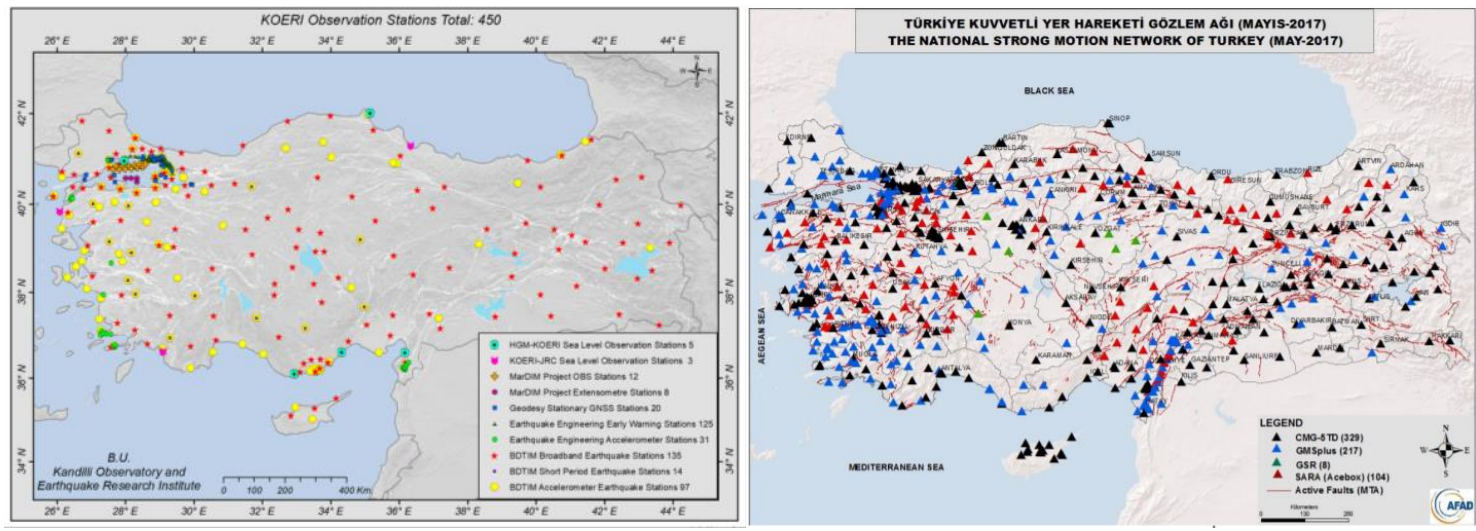

Figure 5. KOERI (www.koeri.boun.edu.tr) and AFAD (www.afad.gov.tr) Seismic Network Around Turkey

\section{Materials and Method}

\subsection{Seismic Observations in Turkey}

The beginning of seismological studies of Kandilli Observatory and Earthquake Research Institute dates back to 1895. The Ottoman Empire started seismic observations by purchasing 2 seismographs after the 1894 Istanbul earthquake. And KOERI has been conducting uninterrupted seismic observations for nearly 126 years. Today, real-time seismic monitoring is carried out with more than 450 earthquake stations spread across the country. Modern technological equipment and communication systems are used in all stations (www.koeri.boun.edu.tr).

Events are recorded real time at the monitoring center digital form obtained from broad-band stations. These are processed using HYPO71 for the hypocenter determination [1]. The seismological division of KOERI determines, as rapidly and accurate as possible, location and size of all earthquakes of magnitude commonly larger than 2.0 that occur in the country [1]. It provides twenty-four hour information service to government agencies, to government public information centers and to news media. This information is also disseminated immediately to the relevant international seismological centers by e-mail, wireless, fax and by internet channels. Observatory has been supplying mainly 3 kind of seismological data: phase readings, waveform and catalogue to the earth scientists in Turkey and all over the world through internet facilities. As of May 2005, KOERI has started to publish waveform data by internet and KOERI also continued to publish continuous data and event base data [1]. Today KOERI has about 40 terabyte data storage unit for backup purposes and made available from there to users by the normal archive date request tools [1]. KOERI has published many catalogs at different times [1]. 
To mitigate the seismic risk and prevent seismic panic, the KOERI has for improving the seismic monitoring system by establishment the broadband digital seismic network in Turkey. Such monitoring system permit rapid acquisition of seismic wave form data, automatic detection of earthquake event and hypocenter determination. The system also provides high quality data appropriate to study on seismology and tectonic as well as earthquake prediction. KOERI provides regular trainings for students and citizens every year in order to increase disaster awareness. These studies have made a significant contribution to increasing the resistance of the society against disasters [23].

The Kandilli Observatory and Earthquake Research Institute (KOERI), being the oldest institution on seismological studies, have observation networks having seismological and engineering purposes. Since 1926, The Kandilli Seismological Division, an integral arm of KOERI, continues to provide seismological observation services with its continuously expanding network distributed throughout Turkey. Today all seismic stations are broadband and they have new technological equipment. Real time data are recorded digital forms at the Regional Earthquake-Tsunami Monitoring Center (RETMC). Today, KOERI Seismic Network has 250 stations in the whole of Turkey [1].

Another earthquake observation institutes is Disaster and Emergency Management Presidency (AFAD) Earthquake Department. AFAD earthquake department is initiated firstly in 1973, it performs strong motion observations. Strong Ground Motion Observation Stations are concentrated mainly in settlements on and around fault systems where large earthquakes are experienced and/or expected in our country. In our country, strong ground motion observations were first started in 1973 within the General Directorate of Disaster Affairs. Turkey Strong Ground Motion Observation Network (TR-KYH) continues its activities under the name of Earthquake Department Strong Ground Motion and Preliminary Damage Estimation Systems Working Group with the establishment of the Disaster and Emergency Management Presidency on 17 December 2009 (www.afad.gov.tr).

In the first years of the establishment of the national network, an observation network was tried to be carried out with analog accelerometers due to the conditions of the day, and digital accelerometers were included in the system since 1993 with the developing technology. In the following years, the number of new generation devices providing real-time data at world standards with high data quality continued to increase rapidly. In 2013, the observation network was completely freed from analog devices, and the goal of an observation network consisting entirely of digital accelerometers was achieved. Today, TR-KYH has taken its place among the world's leading data centers in terms of number of stations, data archive and data quality (www.afad.gov.tr).

The data in AFAD's Turkey Earthquake Monitoring and Evaluation Center are made available to researchers for easy and fast access and analysis over the internet. In this context, AFAD Turkey Acceleration Database and Analysis System (AFAD-TADAS) was put into practice. The system, which can be accessed over the internet, has opened 145 thousand waveforms of 8 thousand 691 earthquakes collected from 795 stations for analysis for now (www.afad.gov.tr).

AFAD-TADAS, which allows the analyzes it provides automatically to earthquake researchers to be made manually with raw data, also makes it possible to store and share. The software system developed with domestic resources is known as AFAD-TADAS (AFAD Turkish Accelerometric Database and Analysis System) as it will serve researchers around the world (www.afad.gov.tr). 
Designed to be user-friendly, AFAD-TADAS enables a large number of users to analyze data in the system at the same time. It was built with modern architecture and open source structure. It has been created in a way that can adapt to the developments in the sector with the infrastructure that will serve for many years. AFAD-TADAS provides service at https://tadas.afad.gov.tr with its reliable and fast internet-based structure. It is offered to academics and researchers with a platform above international standards (www.afad.gov.tr).

AFAD continues to work on different projects for the development of earthquake research and earthquake engineering. In this context, the website of AFAD's Turkey Earthquake Data Center System (AFAD-TDVMS), which unites all earthquake stations in our country, has been renewed. The system, which made all earthquake monitoring stations of different institutions and organizations network in 2014, has gained the appearance of prioritizing a user-friendly approach. Users can access the comprehensive data of AFAD-TDVMS from the renewed web page https://tdvms.afad.gov.tr.

\subsection{Near Real Time Seismic Monitoring}

The beginning of seismological studies of Kandilli Observatory and Earthquake Research Institute dates back to 1895. The Ottoman Empire started seismic observations by purchasing 2 seismographs after the 1894 Istanbul earthquake. And KOERI has been conducting uninterrupted seismic observations for nearly 127 years. Today, real-time seismic monitoring is carried out with more than 260 earthquake stations spread across the country. Modern technological equipment and communication systems are used in all stations.

In order to investigate and to real-time monitor the seismic activity and seismotectonic of Turkey and its vicinity, The Kandilli Observatory and Earthquake Research Institute (KOERI) of Bogaziçi University operates seismic stations countrywide. Besides in 2016, KOERI Regional Earthquake and Tsunami Monitoring Center (RETMC) was accredited by the United Nations as a Tsunami Service Provider in the Northeast Atlantic, Mediterranean and connected seas (in the region covering the Eastern Mediterranean, Aegean, Marmara and Black Sea). KOERI is also a 24/7 National Tsunami Warning Center. The earthquake information is published at the page of the latest current earthquakes in KOERI web site (www.koeri.boun.edu.tr). Today all seismic stations are broadband and they have new technological equipment. Real time data are recorded digital forms at the Regional EarthquakeTsunami Monitoring Center (RETMC). Today, KOERI Seismic Network has more than 450 stations in the whole of Turkey (Figure 6).

Seismicity in Turkey and its surrounding re-gions is monitored by a number of different establishments.RETMC with the FDSN Network Code: KO (Bo gaziçi Uni-versity Kandilli Observatory And Earthquake Research Insti-tute, 2001), is the oldest seismological observation center inTurkey monitoring the earthquake activity 24/7 [25].KOERI is one of the core participants and corporate founderof Observatories \& Research Facilities for European Seis-mology (ORFEUS) and also one of the primary nodes of theEuropean Integrated Data Archive (EIDA), which is an initia-tive within ORFEUS (http://www.orfeuseu.org/data/eida/,last access: October 2019) [25]. RETMC is also an accreditedTsunami Service Provider of the Intergovernmental Coor-dination Group for the Tsunami Early Warning and Mitiga-tion System in the North-eastern Atlantic, the Mediterraneanand connected seas (ICG/NEAMTWS), providing servicesto Eastern Mediterranean, Aegean, Marmara and Black Seassince 2012) [25]. 
Today RETMC is a 24/7 observation center receiving real-time waveform data from 220 national sensors consisting of Broadband (BB), Accelerometer (SM), Short-period (SP) seismometers, along with the national and international seismic stations in the neighborhood area with the bilateral agreements [25]. RETMC network is using mostly the same type of seismometers such as Güralp CMG 3T (300 s and $120 \mathrm{~s}$ ), CMG 40T (30 s), CMG 6T (30 s), CMG 3ESPD (30 s) mainly recording at 100 sps. Relevant information on the equipment of the KOERI network can be found on the web page of RETMC (http://www.koeri.boun.edu.tr/sismo/2/tr/) [25].

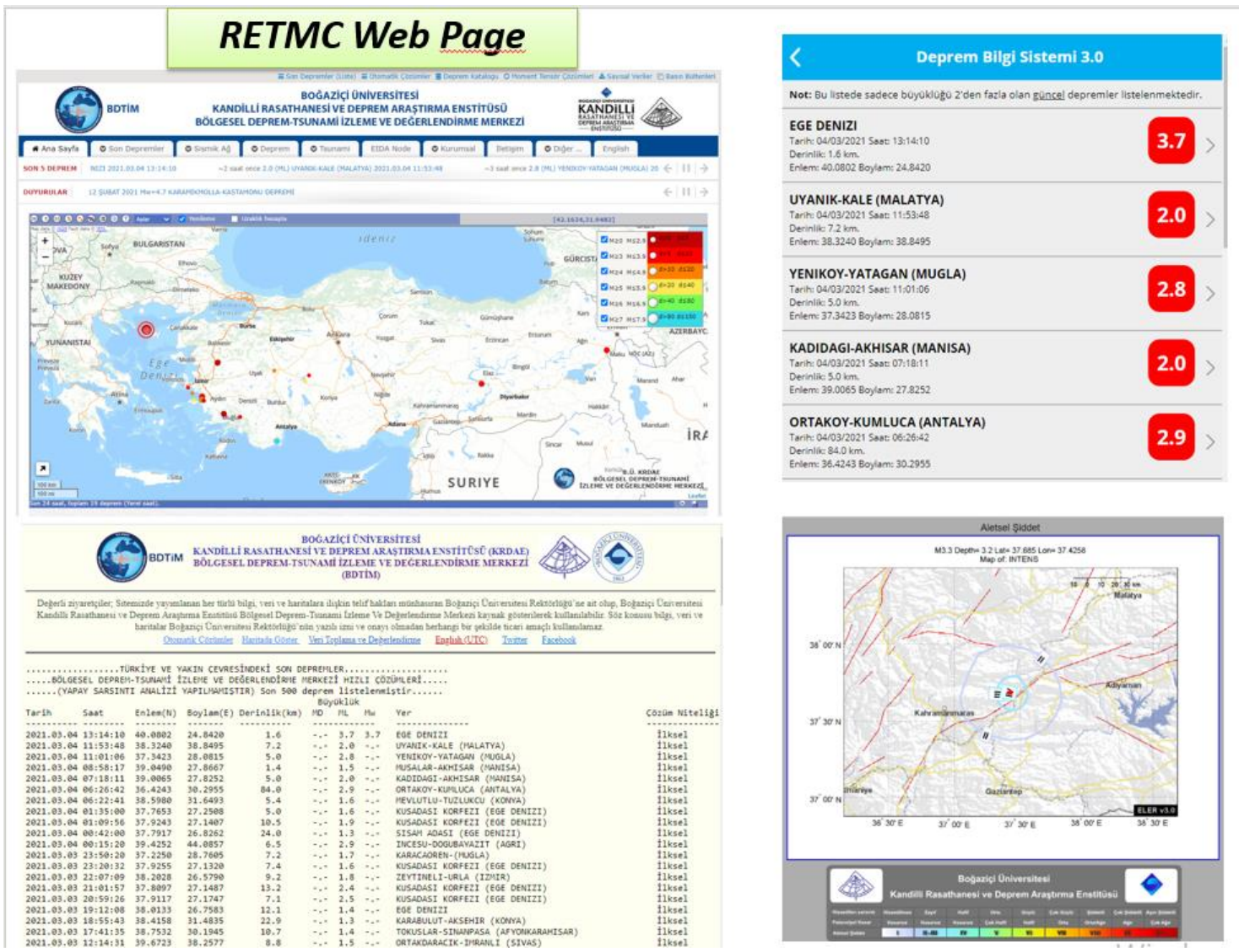

Figure 6.Regional Earthquake-Tsunami Monitoring Center (RETMC) (www.koeri.boun.edu.tr)

To mitigate the seismic risk and prevent seismic panic, the KOERI has for improving the seismic monitoring system by establishment the broadband digital seismic network in Turkey. Such monitoring system permit rapid acquisition of seismic wave form data, automatic detection of earthquake event and hypocenter determination. The system also provides high quality data appropriate to study on seismology and tectonic as well as earthquake prediction. All of the earthquake parameters after the earthquake are distributed automatically. Also, the estimated life losses, shaking maps and damage maps are published immediately after the earthquake (Figure 7). 


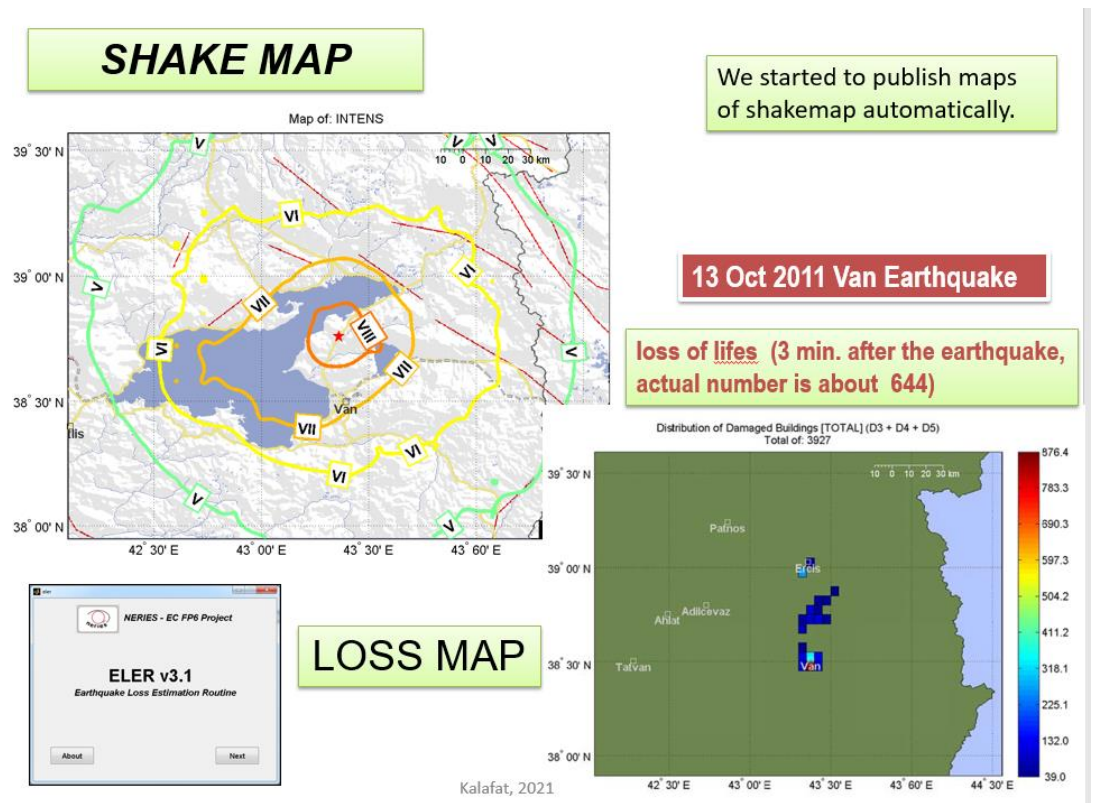

Figure 7. Based on earthquake parameters, risk of the earthquake loss maps produced automatically (www.koeri.boun.edu.tr)

The other earthquake real time monitoring system that is, the Turkey Earthquake Data Center System (AFAD-TDVMS) was established by AFAD for the storage of data received (online/offline) from the Earthquake Observation Stations founded/operated by universities, research centers, agencies and institutions, in order to monitor seismic activity in our country and its surrounding areas from a single center, and to make the data available to all national and international researchers. AFAD-TDVMS was established by the AFAD Presidency in technical cooperation with TUBITAK-ULAKBIM (www.afad.gov.tr).

The Turkish Earthquake Data Center System (TDVMS) is obtained from Turkey earthquake observation stations, which are operated by the Disaster and Emergency Management Presidency (AFAD) Earthquake Department on a 24/7 basis and established to monitor, evaluate and report the earthquake activity in our country and its immediate surroundings. It is a system in which the data obtained by other universities and research institutions carrying out similar studies are collected and shared in a single center. In this way, researchers both in our country and in other countries are provided with fast and reliable access to earthquake data. TDVMS, real-time and offline data obtained from earthquake observation stations established by various institutions, organizations, universities and research centers in our country to monitor earthquakes and observe seismic activity are combined, organized and stored in a single center in accordance with international standards and shared with users (www.afad.gov.tr)..

AFAD continues to work on different projects for the development of earthquake research and earthquake engineering. In this context, the website of AFAD's Turkey Earthquake Data Center System (AFAD-TDVMS), which unites all earthquake stations in our country, has been renewed. The system, which made all earthquake monitoring stations of different institutions and organizations network in 2014, has gained the appearance of prioritizing a user-friendly approach. Users can access the comprehensive data of AFAD-TDVMS from the renewed web page https://tdvms.afad.gov.tr.

By AFAD website, users can view the data numerically and graphically and transfer data by making the desired query according to the criteria selected with the help of the search engine on the internet page. With the UDAP-G-15-04 Project, the ground parameters of the KYH 
Stations belonging to the Observation Network were determined by active and passive geophysical methods and all stations were categorized according to the draft TBDY and international soil classes [25]. Again, with the UDAP-G-14-15 project, after an earthquake, the data coming from KYH stations were processed with rapid resolution and automatic production of USGS ShakeMap (PGA and intensity) [26] maps was provided. All these project products and earthquake reports containing some strong ground motion parameters prepared for $\mathrm{M} \geq 4.5$ earthquakes can be accessed on the TR-KYH website [25]. Efforts to enrich and develop ShakeMap with the ground motion prediction equations produced by earthquakes belonging to our country and its immediate surroundings and the estimated Vs30 map produced for Turkey are continuing [26].

AFAD-RED System (AFAD Earthquake Pre-Damage And Loss Prediction System); Developed in cooperation with our AFAD Earthquake Department and academic cooperation, it is an important tool that produces estimation results about the potential losses that an earthquake may cause, in order to minimize the confusion and information pollution that may occur regarding damage after an earthquake and to help the emergency response teams to be dispatched to the right regions without delay (Figure 8). After an earthquake; by taking the data online from the servers of Turkey Earthquake Observation Networks, integrating it into the system and real-time estimation of losses in the disaster area are made quickly (https://deprem.afad.gov.tr/).

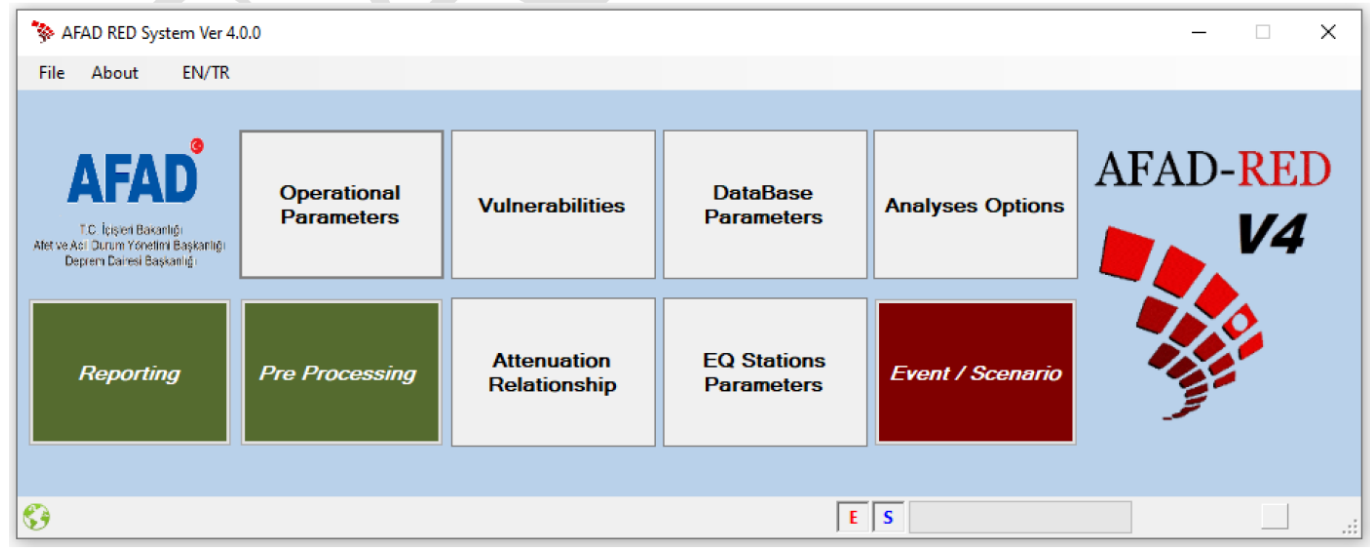

Figure 8. AFAD-RED SOFTWARE (https://deprem.afad.gov.tr/).

By using AFAD RED Software, the theoretical loss relations and actual acceleration values recorded by the Strong Ground Motion recording network operated by the Earthquake Department, iso-acceleration, iso-velocity and iso-intensity maps are generated, and casualties and damage can be calculated and shown on a map of the affected residential areas (https://deprem.afad.gov.tr/).

AFAD-RED produces results on damage and loss that can be caused by both a real earthquake and a scenario earthquake (https://deprem.afad.gov.tr/).

As the system estimate;

- Structural damage (Light, Medium, Heavy and Ruined),

- Number of Patients Requiring Outpatient Treatment, Number of Slightly Injured, Number of Seriously Injured, Number of Loss of Life,

- Number of people who may need temporary accommodation,

- Seismic Intensity Map, Acceleration (PGA) and Velocity (PGV) Maps.

These outputs produced by the software are also used as a base in risk reduction, intervention and improvement studies and shared with relevant institutions. Figure 9 shows as sample 
intensity map for $\mathrm{Mw}=6.8$ produced by $\mathrm{AFAD}-\mathrm{RED}$.

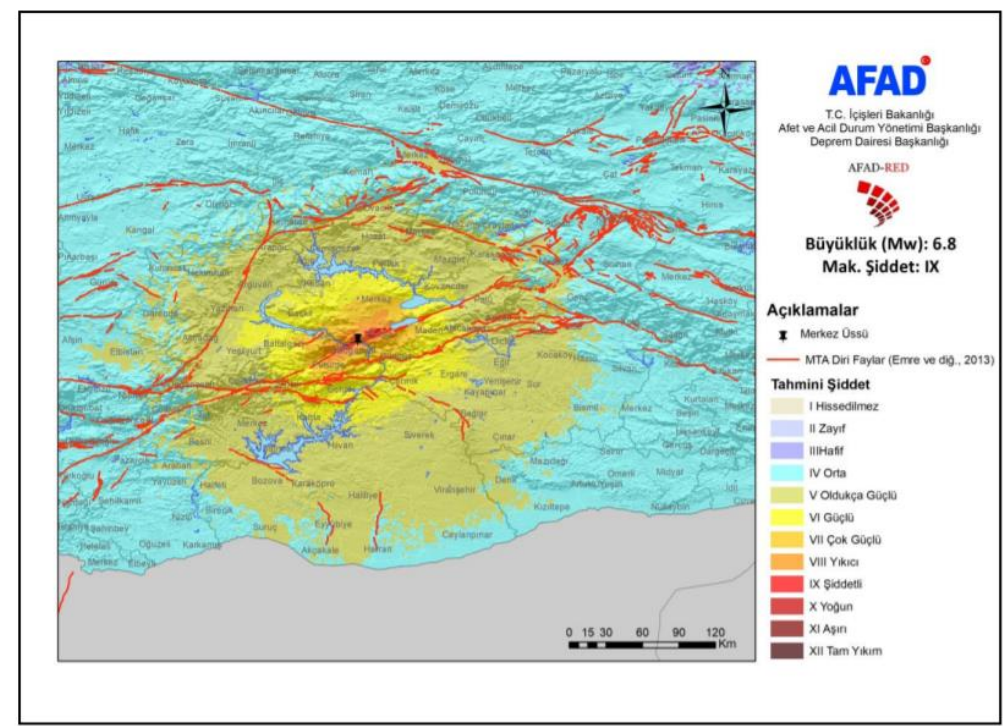

Figure 9. Elazıg earthquake intensity map from AFAD-RED (https://deprem.afad.gov.tr/).

\subsection{Earthquake Information System: Mobile Application}

Smartphone applications are important tool for earthquake information systems. Mobile applications collects information from people who felt an earthquake and creates maps that show what people experienced and the extent of damage. Step by step user manual of the mobile application was shown at Figure 10.

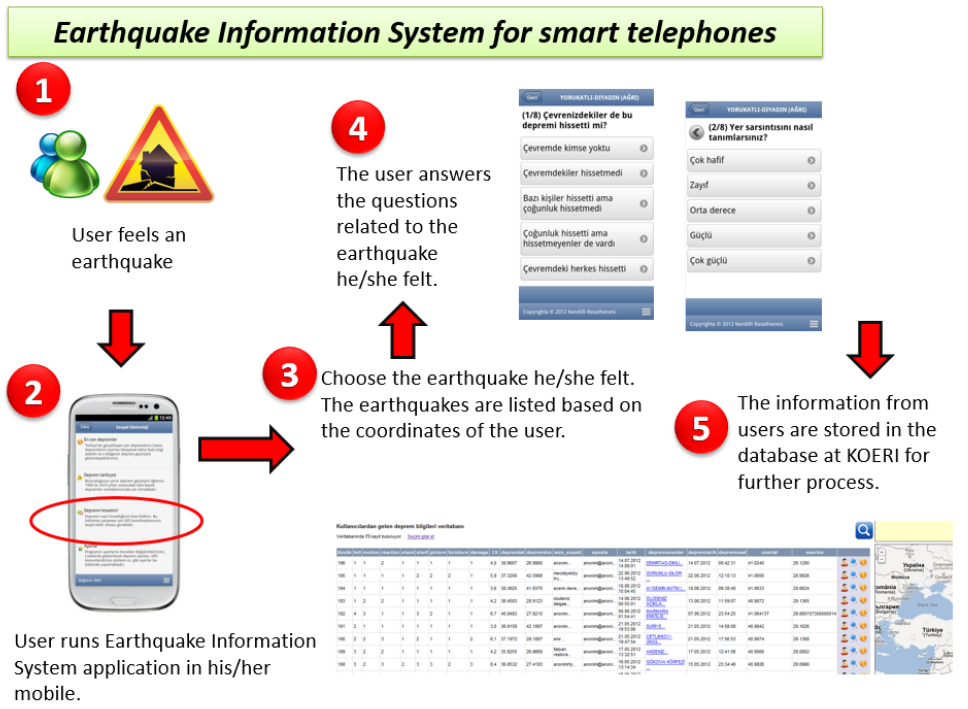

Figure 10. Earthquake Information System Step by Step User Manual [1]

The Earthquake Information System, developed by the Kandilli Observatory and Earthquake Research Institute, provides the opportunity to inform users about earthquakes in and around Turkey, and to access data on Turkey's seismic history. At the same time, enabling users to view historical earthquakes that have occurred in their location on the map. The application also offers users who sense an earthquake and have installed the application on their mobile phones or tablets, to convey how they felt about the earthquake to the Kandilli Observatory and Earthquake Research Institute. In this way, when there is an earthquake, it will be possible to 
determine where and how the earthquake was felt and the geographical distribution of the damage or effects of the earthquake. Figure 11 shows the smartphone application of KOERI.

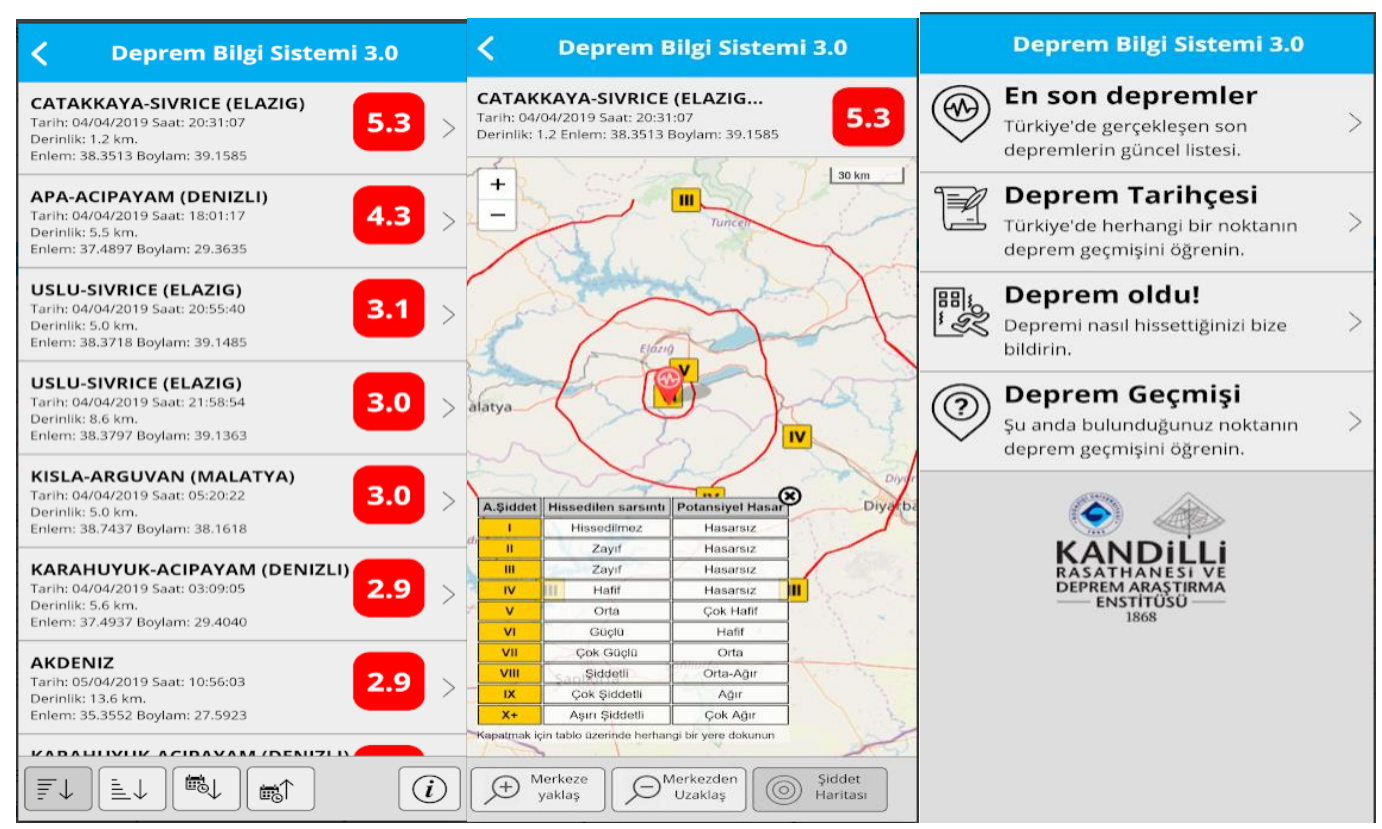

Figure 11 Kandilli Earthqauke Information Mobile Application (www.koeri.boun.edu.tr)

AFAD Earthquake Information Mobile Application has warnings and precautions shared in case of disasters and emergencies. The application, which will provide earthquake information at the first stage, will also provide users with flood, rockfall, landslide, tornado and storm early warnings with future updates. Figure 12 shows the smartphone application of AFAD. Through mobile application, latest earthquake location is shown on the map and location, magnitude and depth information of the earthquake are provided to users.

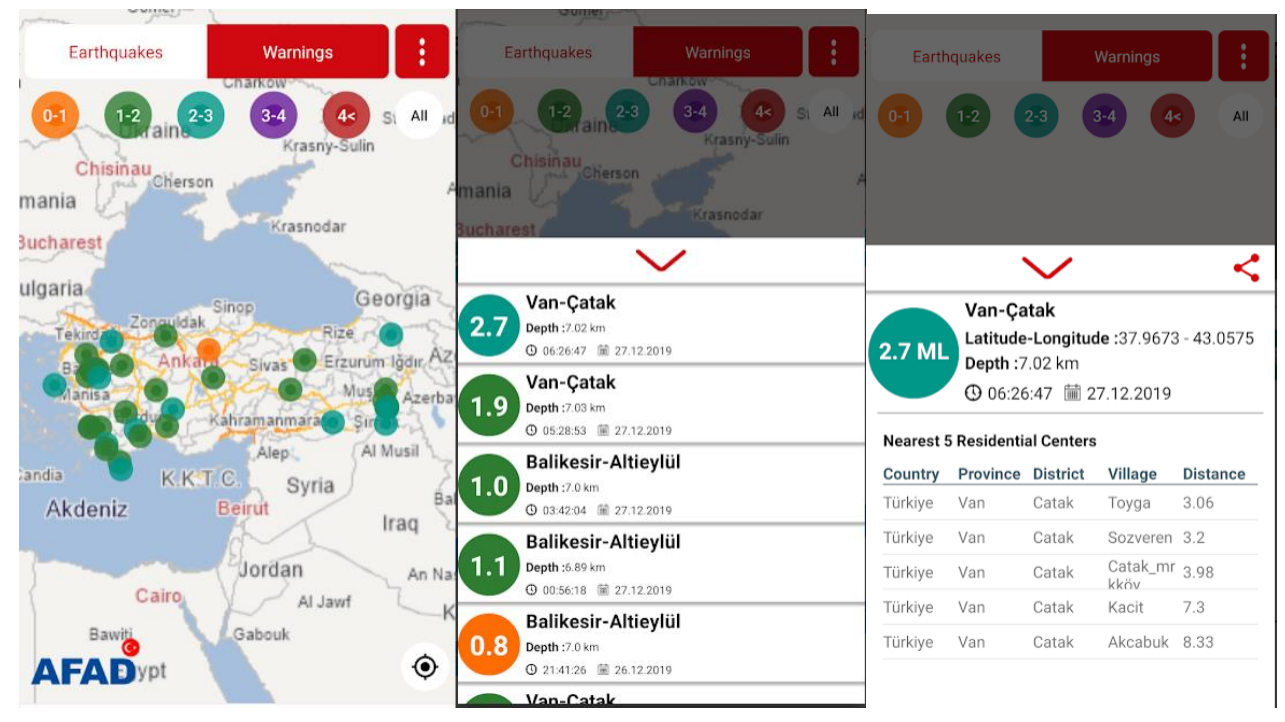

Figure 12 AFAD Earthquake Information Mobile Application (www.afad.gov.tr) 


\section{Results}

The collection of the earthquake dataset is important for development of reliable earthquake catalogs that are basement of the seismic hazard assessment. In Turkey, two important seismic network operators, KOERI and AFAD earthquake studies provides information as basement to evaluate the regional seismic hazard assessment and evaluate seismic risk in a region. AFAD and KOERI seismic observation systems collect earthquake information, and produce intensity maps and gives information about approximate losses immediately after an earthquake. Also, earthquake information mobile applications are important to produce human based earthquake intensity maps after an earthquake that is important to decide the severity of the earthquake.

\section{Discussion}

To mitigate the seismic risk and prevent seismic panic, the KOERI and AFAD has improved the seismic monitoring system by establishment the broadband digital seismic network in Turkey. Such monitoring system permit rapid acquisition of seismic wave form data, automatic detection of earthquake event and hypocenter determination. The system also provide high quality data appropriate to study on seismology and tectonic as well as earthquake prediction. KOERI and AFAD provide regular trainings for students and citizens every year in order to increase disaster awareness. These studies have made a significant contribution to increasing the resistance of the society against disasters.

\section{Conclusions}

Due to its tectonic structure, Turkey is earthquake prone country where the majority of its land is under seismic hazard. Seismic activity in Turkey and its near vicinity has been observed instrumentally since 1900s. Earthquake Department of Republic of Turkey Prime Ministry's Disaster and Emergency Management Presidency (AFAD), and Regional Earthquake-Tsunami Monitoring Center (RETMC)-Kandilli Observatory and Earthquake Research Institute (KOERI) of Bogazici University are the two main seismic network operators in Turkey. They periodically publish data in the form of catalogues and bulletins for internal and external information exchange. The developed earthquake catalogue and intermediate output integrated earthquake database from AFAD and KOERI dataset is important contribution for future earthquake related studies especially seismic hazard and risk assessment studies in Turkey and its near vicinity.

\section{Author Contribution}

ACZ, DK and SOA all contributed to the article in conceptualization, literature evaluation and preparation.

\section{References}

[1] Cambaz, M. D., Özer, M., Güneş, Y., Ergün, T., Öğütcü, Z., Altuncu-Poyraz, S., .. \& \& Özener, H. (2021). Evolution of the Kandilli observatory and earthquake research institute (KOERI) seismic network and the data center facilities as a primary node of EIDA. Seismological Society of America, 92(3), 1571-1580. 
[2] Duman, T. Y., Çan, T., Emre, Ö., Kadirioğlu, F. T., Baştürk, N. B., Kılıç, T., ... \& Kurt, A. İ. (2018). Seismotectonic database of Turkey. Bulletin of Earthquake Engineering, 16(8), 3277-3316.

[3] Ansari, K., Corumluoglu, O., \& Sharma, S. K. (2017). Numerical simulation of crustal strain in Turkey from continuous GNSS measurements in the interval 2009 2017. Journal of Geodetic Science, 7(1), 113-129.

[4] D. Kalafat (2021) Kuşadası'nın Deprem ve Tsunami Potansiyeli Orta Ege Bölgesinin Sismolojik Özellikleri, Kuşadası Belediyesi Deprem Ve Kentsel Dönüşüm Çalıştayı, 8 Aralık 2021, Kuşadası-Aydın.

[5] Kalafat D, M. N. Toksöz (2017). An overview of the seismic activity and gaps in the Marmara Sea Area, JpGU AGU Joint Meeting 2017 Japan Geoscience Union, Presentation Number: SSS13-P12, 20-25 May1s 2017 Makuhari Messe International Conference Hall, Makuhari-Tokyo, Japan.

[6] Kalafat, D., \& Toksoz, M. N. (2015, December). A Catalogue of Source Parameters of Moderate and Strong Earthquakes for Turkey and its Surrounding Area (1938-2015). In AGU Fall Meeting Abstracts (Vol. 2015, pp. S11A-2736).

[7] Taymaz, T., Tan, O., \& Yolsal, S. (2004). Active tectonics of Turkey and surroundings: Seismic risk in the Marmara Sea region. In Proc. 1st International Workshop on Active Monitoring in the Earth Geophysics (IWAM04), Mizunami, Japan, Extended Abstract Book (pp. 110-115).

[8] Duman, T. Y., \& Emre, Ö. (2013). The East Anatolian Fault: geometry, segmentation and jog characteristics. Geological Society, London, Special Publications, 372(1), $495-$ 529.

[9] Ambraseys, N. N., \& Jackson, J. A. (1998). Faulting associated with historical and recent earthquakes in the Eastern Mediterranean region. Geophysical Journal International, 133(2), 390-406.

[10] Tan, O., Pabuçcu, Z., Tapırdamaz, M. C., İnan, S., Ergintav, S., Eyidoğan, H., ... \& Kuluöztürk, F. (2011). Aftershock study and seismotectonic implications of the 8 March 2010 Kovancilar (Elazı̆̆, Turkey) earthquake (MW=6.1). Geophysical Research Letters, 38(11).

[11] Kalafat, D., K. Kekovalı, P. Deniz, Y. Güneş, A. Pınar, G. Horasan (2008). 31 Temmuz-1 Ağustos 2005 ve 20-27 Aralık 2007 Afşar-Bala (Ankara) Deprem Dizisi, DAYK2008, T.C. Sakarya Üniversitesi Doğal Afetler ve Yerbilimleri Kulübü, 1. Ulusal Doğal Afetler ve Yerbilimleri Sempozyumu, Bildiriler Kitabı (in Turkish), s. 21-30, 1922 Mart 2008, Adapazar1.

[12] Kadirioğlu, F. T., Kartal, R. F., Kılıç, T., Kalafat, D., Duman, T. Y., Azak, T. E., ... \& Emre, Ö. (2018). An improved earthquake catalogue ( $\mathrm{M} \geq 4.0)$ for Turkey and its near vicinity (1900-2012). Bulletin of Earthquake Engineering, 16(8), 3317-3338

[13] Gutenberg B, Richter CF (1954) Seismicity of the earth and associated phenomena, 2nd edn. Princeton University Press, Princeton, $N J$

[14] Alsan E, Tezuc an L, Bath M (1975) An earthquake catalogue for Turkey for the interval 1913-1970. Kandilli Observatory Seismological Department ÇengelköyIstanbul, Turkey and Seismological Institute Box 517, S-751 20 Uppsala, Sweden 
[15] Ayhan E, Alsan E, Sancaklı N, Üçer SB (1981) Turkey and surrounding earthquake catalogue 1881-1980. Bogazici University Publications, Istanbul

[16] Ambraseys NN, Finkel CF (1987) Seismicity of Turkey and neighbouring regions, 1899-1915. Ann Geophys 5B(6):701-726

[17] Ambraseys NN, Jackson JA (1998) Faulting associated with historical and recent earthquakes in the Eastern Mediterranean region. Geophys J Int 133:390-406

[18] Kalafat D, Günes, Y, Kekovalı K, Kara M, Deniz P, Yılmazer M (2011) A revised and extended earthquake catalogue for Turkey since 1900 (M C 4.0). Bogazici University, Kandilli Observatory and Earthquake Research Institute, Istanbul

[19] Kadirioğlu, F. T., Kartal, R. F., Kılıç, T., Kalafat, D., Duman, T. Y., Azak, T. E., ... \& Emre, Ö. (2018). An improved earthquake catalogue ( $\mathrm{M} \geq 4.0)$ for Turkey and its near vicinity (1900-2012). Bulletin of Earthquake Engineering, 16(8), 3317-3338.

[20] Erdik, M., \& Öner, S. (1982). A rational approach for the probabilistic assessment of the seismic risk associated with the North Anatolian Fault. In Multidisciplinary Approach to Earthquake Prediction (pp. 115-127). Vieweg+ Teubner Verlag, Wiesbaden.

[21] Erdik, M., Biro, Y. A., Onur, T., Sesetyan, K., \& Birgoren, G. (1999). Assessment of earthquake hazard in Turkey and neighboring. Annals of Geophysics, 42(6).

[22] Kayabali, K. (2002). Modeling of seismic hazard for Turkey using the recent neotectonic data. Engineering Geology, 63(3-4), 221-232.

[23] D. Kalafat (2019). Contribution of Seismic Network for Earthquake Risk Identification and Community Resilience: A Case Study in Turkey, The 6th International Symposium on Engineering and Natural Sciences, ISEANS-0010, November 19-22, 2019 Bangkok, Thailand.

[24] Woessner J, Danciu L, Giardini D, Crowley H, Cotton F, Grünthal G, Valensise G, Arvidsson R, Basili R, Demircioglu MN, Hiemer S, Meletti C, Musson RW, Rovida AN, Sesetyan K, Stucchi M, the SHARE consortium (2015) The 2013 European Seismic Hazard Model: key components and results. Bull Earthq Eng. doi:10.1007/s10518-015-9795-1

[25] Cambaz, M. D., Turhan, F., Yılmazer, M., Kekovalı, K., Necmioğlu, Ö., \& Kalafat, D. (2019). A review on Kandilli Observatory and Earthquake Research Institute (KOERI) seismic network and earthquake catalog: 2008-2018. Advances in Geosciences, 51, 1523.

[26] Tepeugur,E.,Kuru,T.,Apak,A.,Kökbudak,D.,Tekin,K.,Ateş,E.,Sezer,S.,Kaplan,M.,Eravc 1,B.,Yalçın,D.,Baykal,M.,Çetin,C., Şahin,C.(2017). AFAD Kuvvetli Yer Hareketi Gözlem Sistemlerine İlişkin Son Gelişmeler. 4. Uluslararası Deprem Mühendisliği ve Sismoloji Konferansi 11-13 Ekim 2017 - ANADOLU ÜNIVERSITESI - ESKIŞEHIR

[27] Wald, D. J., C. B. Worden, V. Quitoriano, and K. L. Pankow (2006). ShakeMap® Manual, Technical Manual, Users Guide and Software Guide; http://pubs.usgs.gov/tm/2005/12A01/pdf/508TM12-A1.pdf. 